were panned out from 29 stream-sediment samples, while four samples from a large glaciofluvial plain will be analysed untreated.

\section{Concluding remarks}

The aeroradiometric survey successfully reduced the areal extent of the previously known gamma anomalies by about $50 \%$. This was due to the use of equipment with better resolution and a helicopter with better performance, compared with the 1982 survey. Consequently, smaller areas had to be covered by the systematic chip sampling, which enabled the collection of larger samples in closer spaced grids than originally planned.

The acquired geophysical and geochemical data will be treated statistically in co-operation with IMSOR (Institute of Mathematical Statistics and Operations Research), Technical University of Denmark, and will be interpreted in a final report.

Acknowledgements. The authors thank J. Lau and O. Plesner for invaluable support from the base camp at Narsarsuaq; E. Dam and I. Rytved for their spirited contribution in the field laboratory; L. Thorning for assistance during the geophysical survey; J. L. Pedersen and L. Melchior Larsen for comments on the report; and finally the Swiss mountaineering team and the British geophysical staff for professional and enjoyable co-operation.

\section{References}

Armour-Brown, A., Tukiainen, T. \& Wallin, B. 1980: The South Greenland regional exploration programme. Rapp. Grønlands geol. Unders. 100, 83-86.

Armour-Brown, A., Tukiainen, T., Wallin, B., Bradshaw, C., Emeleus, C. H. 1983: Uranium exploration in South Greenland. Rapp. Grønlands geol. Unders. 115, 68-75.

Blaxland, A. B., van Breemen, O., Emeleus, C. H. \& Anderson, J. G. 1978: Age and origin of the major syenite centres in the Gardar province of South Greenland: $\mathrm{Rb}-\mathrm{Sr}$ studies. Bull. geol. Soc. Am. 89, 231-244.

Bradshaw, C. 1985: The alkaline rocks of the Motzfeldt Centre; progress report on the 1984 field season. Rapp. Grønlands geol. Unders. 125, 62-64.

Emeleus, C. H. \& Harry, W. T. 1970: The Igaliko nepheline syenite complex. General description. Bull. Grønlands geol. Unders. 85 (also Meddr Grønland 186,3) 116 pp.

Thomassen, B. \& Tukiainen, T. 1987: The Motzfeldt 87 project. Field report. Unpubl. intern. GGU rep., 16 pp.

Tukiainen, T. 1986: Pyrochlore in the Motzfeldt Centre of the Igaliko nepheline syenite complex, South Greenland. Final Report. Unpubl. intern. GGU rep., 98 pp.

Tukiainen, $T$. in press: Niobium-tantalum mineralisation in the Motzfeldt Centre of the Igaliko nepheline syenite complex, South Greenland. Spec. Publ. Soc. Geol. Appl. Min. Dep. 5. Tukiainen, T., Bradshaw, C. \& Emeleus, C. H. 1984: Geological and radiometric mapping of the Motzfeldt Centre of the Igaliko Complex, South Greenland. Rapp. Grønlands geol. Unders. 120, 78-83.

\title{
Greenland ice cap aeromagnetic survey 1987: completion of the survey over the southern end of the Greenland ice cap
}

\author{
L. Thorning, M. Bower, C. D. Hardwick and P. Hood
}

The Geological Survey of Greenland (GGU), the Geological Survey of Canada (GSC), and the National Aeronautical Establishment (NAE) of the National Research Council of Canada are cooperating in the GICAS project. The objective of the project is to achieve a regional, aeromagnetic coverage of the Greenland ice cap, and to produce magnetic anomaly maps for use in research on the large scale geological structures. Field work was carried out in 1983, 1984, and 1985 (Thorning et al. , 1984, 1985, 1986). The work reported in this note was originally planned for April 1986, but for technical reasons it had to be postponed until April 1987. Consequently, the subsequent processing of all the data into a regional magnetic anomaly map has been correspondingly delayed.

\section{Field work}

In 1985 parts of the southernmost ice cap were covered (Thorning et al., 1986), and the 1987 operation was planned to make the coverage complete over this part of the ice cap. The operation was carried out as part of a larger programme to compile a magnetic anomaly map of North America, which also involved work in northern Canada and the Nares Strait region between Canada and Greenland, and a tie-line from the North Greenland continental shelf over the ice cap along its western margin to Søndre Strømfjord. Tie-lines from Alert to Svalbard to Iceland had to be abandoned due to unfavourable weather conditions around Svalbard.

The flights for the GICAS were based at Søndre 


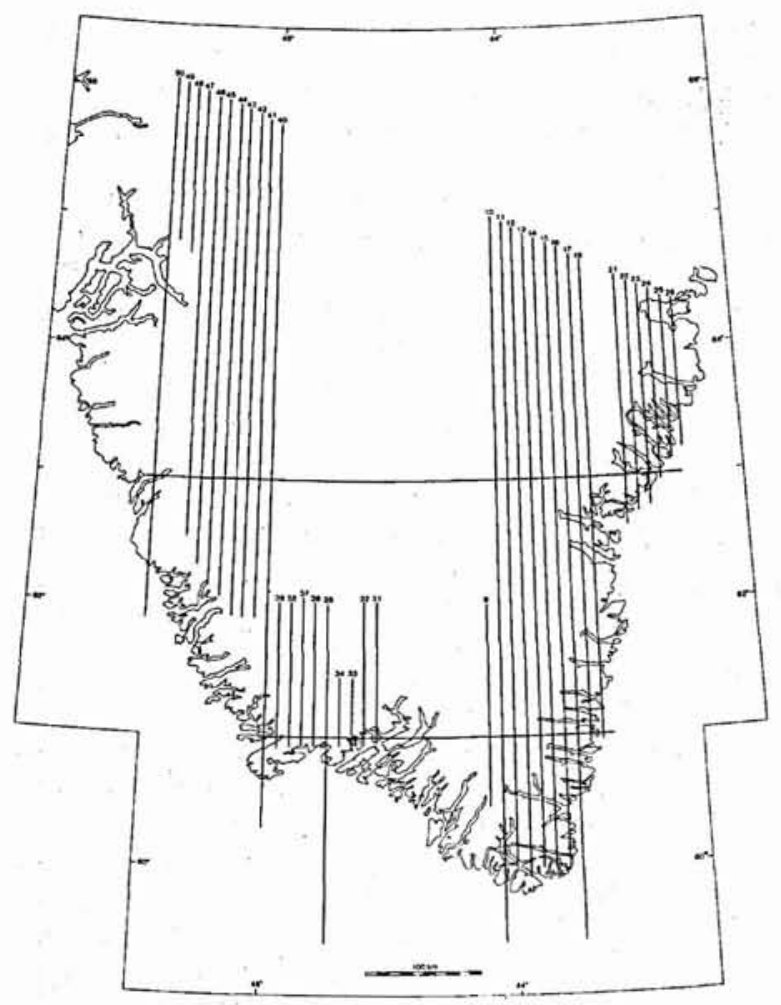

Fig. 1. Schematic representation of lines flown in April 1987. Approximately 8000 line $\mathrm{km}$, line spacing approximately 10 $\mathrm{km}$, flight altitude $1000 \mathrm{ft}$ over ice surface or tops of mountains in ice-free, coastal areas.

Strømfjord airport, and Narsarsuaq was used for refuelling. A base magnetometer was operated in Søndre Strømfjord during flights to record diurnal variations.

The aeromagnetic data comprise both total field and three gradients (Hardwick, 1982). The NAE Convair 580 aircraft (C-FNRC, Research-9), already well equipped for navigation over the ice cap, carried a new global satellite navigation system.

The lines flown in April 1987 are shown in fig. 1. As in previous surveys the line separation is approximately 12 minutes of longitude which, at the latitude of Narsarsuaq, corresponds to $10.9 \mathrm{~km}$ and at the northern end of the area to $9.5 \mathrm{~km}$. Approximately 8000 line kilometres were flown, including two additional east-west tie-lines. The coverage is now nearly complete over the southern part of the ice cap, with only a few gaps between the lines which it was not economic to fill out.

\section{Further work}

The data are undergoing post-flight processing at NAE, and will be transferred to GGU for further proc- essing in the spring of 1988 . In the field, inspection of the data confirms the observations from the 1985 survey (Thorning et al., 1986) and closes the gaps in the coverage of major geological features. All data acquired in 1983-1987 (fig. 2) will be compiled into a magnetic anomaly map covering the entire area. No flying is contemplated in 1988, but it is hoped later to survey the triangular area north of Angmagssalik up to $71^{\circ}$ north and across the ice cap.

Acknowledgements. Besides the authors the following participated in the field operations: W. T. Chevrier (aircraft captain), J. Aitken (co-captain), T. Slack, G. Hoftyzer, W. Budarick (project crew), M. Larsen (maintenance crew chief), S. O'Connor and D. Blythe (maintenance crew) all from NAE.

\section{References}

Hardwick, C. D. 1982: Benefits of NAE 3-axis magnetic gradiometer. Northern Miner 68(24), B1-B2.

Thorning, L., Bower, M., Hardwick, C. D. \& Hood, P. J. 1984: Greenland ice cap aeromagnetic survey 1983: acquisition of high sensitivity total field and gradient magnetic data. Rapp. Grønlands geol. Unders. 120, 32-36.

Thorning, L., Bower, M., Hardwick, C. D. \& Hood, P. J. 1985: Greenland ice cap aeromagnetic survey 1984: reconnaissance lines in southern Greenland. Rapp. Grønlands geol. Unders. 125, 83-84.

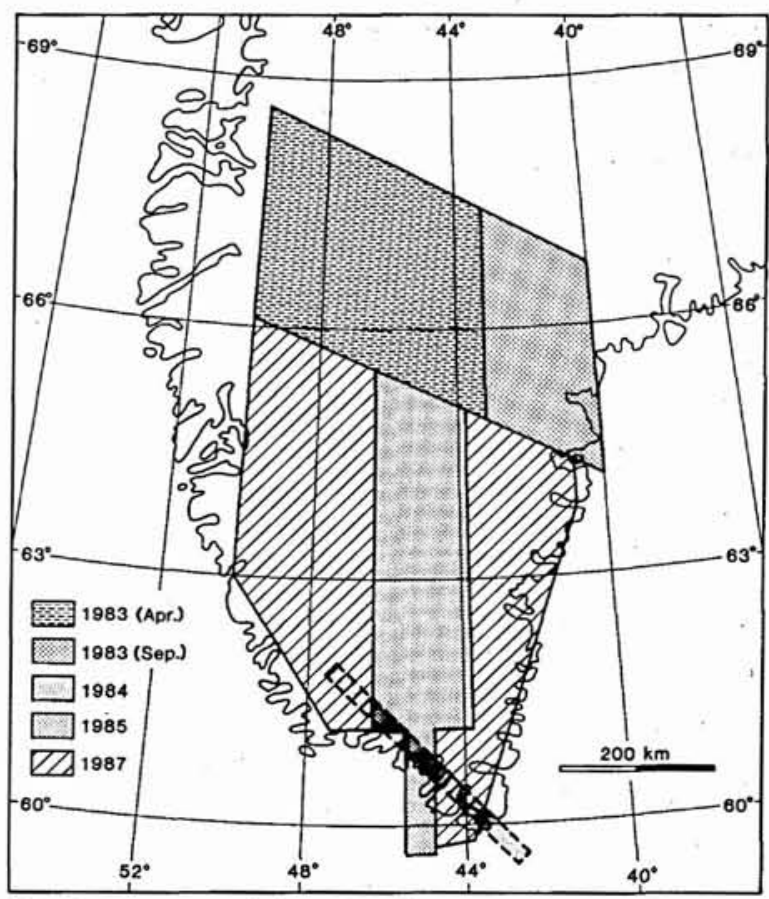

Fig. 2. Summary of Greenland ice cap aeromagnetic survey coverage 1983-1987. 
Thorning, L., Bower, M., Hardwick, C. D. \& Hood, P. J. 1986: Greenland ice cap aeromagnetic survey 1985: magnetic measurements over the southern end of the Greenland ice cap. Rapp. Grønlands geol. Unders. 130, 86-90.
M. B.,

Flight Res. Sect.,

Bldg. $U-61$,

Nat. Research Council,

Montreal Road,

Ottawa, Ontario,

Canada, K1A OR6.
C. D. H.,

Flight Res. Lab., Nat. Research Council, Montreal Road,

Ottawa, Ontario, Canada, KIA OR6.
P. J. H. Regional Geophysics Subdiv., Resource Geophys. and Geochem. Div. Geological Survey of Canada, 601 Booth Street, Ottawa, Ontario, Canada, K1A OES.

\title{
Reconnaissance investigations in the Skjoldungen region, South-East Greenland
}

\author{
Troels F. D. Nielsen and Jan C. Escher
}

From 1 July to 25 August 1987 a GGU expedition made reconnaissance investigations between $62^{\circ} \mathrm{N}$ and $64^{\circ} 20^{\prime} \mathrm{N}$ in South-East Greenland. The programme was a continuation of the investigations in the Ammassalik/ Angmagssalik district in 1986 (Kalsbeek \& Nielsen, 1987) and the completion of the fieldwork describing areas in East Greenland between $62^{\circ} 30^{\prime} \mathrm{N}$ and $65^{\circ} 45^{\prime} \mathrm{N}$ for the planned map sheet (no. 14) in the 1:500 000 geological map series. The Skjoldungen district was known mainly from previous boat-supported work in the coastal areas as described by Bridgwater \& Gormsen, 1969; Andrews et al., 1971, 1973; Bridgwater et al., 1976; Escher \& Nielsen, 1982, 1983; Nielsen \& Escher 1985 and Escher et al., 1986.

\section{Organization}

The investigations were carried out as in 1986 in close co-operation with a team from the Geodetic Institute, Copenhagen, led by T. I. Hauge Andersson.

During an earlier airborne reconnaissance a camp site with a natural airstrip was located in the innermost part of Kagssortôq fjord (fig. 1). All equipment and personnel were transported to the base camp with a de Havilland Twin Otter (chartered by GI from Flugfélag Norourlands hf., Iceland) from Kulusuk airfield near Ammassalik. The field work was supported by an Aerospaciale Ecureil (AS 350 B1) helicopter (chartered by GGU from Uni-Fly, Denmark). Both aircraft were chartered through Greenlandair Charter $\mathrm{A} / \mathrm{S}$ and shared by GI and GGU.

The base camp was manned by P. Bay (materials, GGU), R. Fedder (cook, GGU), J. Wulff (radio communications, shared by GI and GGU) supported by $A$.
Petersen (GGU) and P. B. Andersen (GI), both students. The helicopter was operated by two crews: S. Forsstedt (pilot) and S. Nielsen (maintenance) during the first three and the last two weeks of the season and by U. Stoller (pilot) and C. Jørgensen (maintenance) between 23 July and 12 August. The preparation for the field work and co-ordination in the field were undertaken by T. F. D. Nielsen (GGU) in co-operation with T. I. Hauge Andersson (GI).

The group of geologists included five two-man teams (fig. 1): a northern mapping team: J. C. Escher (GGU) and M. J. Ryan (Portsmouth Polytechnic); a southern mapping team: B. Chadwick (University of Exeter) and B. J. Walton (Portsmouth Polytechnic); two interchangeable mapping teams: M. T. Rosing (Geologisk Museum, Copenhagen), V. N. Vasudev (Department of Mines and Geology, Bangalore, India), T. F. D. Nielsen (GGU) and A. Petersen (GGU); and an age dating team through the last four weeks of the season: F. Kalsbeek (GGU) and P. N. Taylor (Oxford University). Reporting on mineral occurrences was assigned to V. N. Vasudev and M. J. Ryan.

The northern and southern reconnaissance teams were mainly based in field camps and were supported by reconnaissance with a helicopter and rubber dinghy. The rest of the group worked mainly from the base camp, also supported by both a helicopter and rubber dinghies.

\section{Geology}

The area investigated during the field season broadly corresponds with the Archaean terrain of South-East Greenland (Andrews et al., 1973) which is bounded to 